\title{
Soviet and American Precursors to the Gamification of Work
}

\author{
Mark J. Nelson \\ Center for Computer Games Research \\ ITU Copenhagen \\ Copenhagen, Denmark \\ mjas@itu.dk
}

\begin{abstract}
A number of commentators have proposed adapting elements derived from game mechanics to workplaces, to motivate employees via techniques that, the argument goes, have proven successful in a videogame context, and thus may have wider motivational applications. This general strategy has become grouped under the term "gamification". I argue the gamification-of-work movement has at least two major precursors, one in the Soviet Union of the early to mid 20th century, and another in American management of the late 20 th and early 21 st centuries. The Soviet approach focused on games to increase productivity, via experiments ranging from purely competitive games directly tied to productivity, to attempts at morale-building via team games and workplace self-expression. The American management approach focused more strongly on a sense of childhood play, aiming to weaken the work/play split, but often with games and competition integrated into the framework. Neither approach is identical to the gamification-of-work movement, but there exist significant overlaps, and thus both the historical movements themselves, and the critiques that have been directed at them, should be studied in order to better understand how to approach current attempts in light of past experiences.
\end{abstract}

\section{INTRODUCTION}

A recent trend, the "gamification of work", aims to integrate game-design elements into the workplace, to improve productivity and motivation. Some predict a wholesale change in how work is conceptualized [Burke and Hiltbrand, 2011, Smith, 2011] and the growth of a billion-dollar market in workplace gamification [Silverman, 2011]. What its proponents hope to do is to capture some of the motivating power that game mechanics appear to have, and redirect them towards non-entertainment uses. In entertainment contexts, people play many hours of videogames without being forced or paid to do so (while enjoying it!). The hope is that there is an underlying motivational force at

Permission to make digital or hard copies of all or part of this work for personal or classroom use is granted without fee provided that copies are not made or distributed for profit or commercial advantage and that copies bear this notice and the full citation on the first page. To copy otherwise, to republish, to post on servers or to redistribute to lists, requires prior specific permission and/or a fee.

MindTrek 2012, October 3-5, 2012, Tampere, FINLAND.

Copyright 2012 ACM 978-1-4503-1637-8/12/10 ...\$15.00. work that can be bottled and redirected towards motivating employees and increasing productivity.

Gamification of work presents itself as a new movement: game mechanics, the argument goes, have long motivated videogame players, but just now are we realizing that they can be also applied to motivate workers performing serious, productive work. Two precursor movements, however, have had quite similar goals. The Soviet Union's extensive experiments with workplace-based "socialist competition" hoped to use the power of games and competition to replace capitalist competition with something that would be simultaneously more engaging and humane, yet would motivate high productivity. In a different country and era, the 1990s-2000s American management trend of "fun at work" proposed reimagining the workplace as a fun and playful locale rather than one of work and drudgery, recapturing some of what was seen as an intrinsic, child-like play; in practice this trend included many game-like elements (though not all play and fun is made up of game mechanics).

To the extent the goals and methods of these movements overlap with the gamification-of-work movement, it's useful to investigate how this third coming of the gameful workplace builds on or diverges from the previous two. The novelty myth in gamification discourse obscures these connections, which, besides any concerns for historical accuracy, misses an opportunity to consider how current methods might build on successes and avoid failures of the previous strategies. Deterding et al. [2011] take a first step towards historical contextualization by discussing connections to previous proposals for "serious" uses of games, such as the serious-games movement, training games, edutainment, and so on. Here, I focus on precursor movements specifically based in workplace management. I sketch the Soviet and American approaches, and several critiques each has attracted, as a first step towards integrating these historical precursors into the current debate-something that could benefit from much more work, as neither movement has yet received a full historical treatment in its own right.

\section{SOCIALIST COMPETITION}

The attraction of gamification to the Soviet Union is not hard to fathom: It promised a way to motivate workers without relying on capitalist-style monetary incentives. Lenin [1917/1964] proposed a theory of "socialist competition", in which workers, groups of workers, or factories would compete with each other to motivate greater production. A wide variety of experiments followed. A factory might be awarded points for its performance, and win commendations as it 
surpassed various point thresholds. Teams building a bridge could compete to see which side progresses fastest. Borrowing a symbolic-motivation strategy used by armies, particularly productive factories or workers might be awarded a medal such as the Order of the Red Banner of Labor. There are many more examples, but to my knowledge no comprehensive study of the Soviet use of game-like elements in an industrial context yet exists - hopefully a gap that will be filled in due course by historians. However, a number of examples from the construction of Magnitogorsk (Magnitostroi) are discussed by Kotkin [1993]. Zemtsov [1991] provides some general background.

Opponents from the left objected to socialist competition. Communism had promised to eliminate the alienation of workers, with monetary motivation replaced by a real engagement with one's work. Replacing money with bridgebuilding games, giant commendation banners, and shiny badges might seem more like a kind of bizarro-world capitalism, with payment in trinkets and coercion via rankings, rather than a real change in the relation between workers and work. Trotsky leveled just such a charge of "backward capitalism ... under the whip of a bureaucracy", though he left the door open to "competition, whose roots lie in our biological inheritance" returning in a different guise [Trotsky, 1937/2004, p. 97]. ${ }^{1}$ And in one anecdote [Kotkin, 1993, p. 79], a carpenter and veteran Soviet partisan complained that he was happy to work to build the new socialist country, but it was nobody's business to tell him how to work, or line him up in competition against a comrade.

Lenin and later Stalin [1929/1954] emphasized that socialist competition really was supposed to be about real motivation. The term was replaced by "socialist emulation", distinguishing emulation, where those further behind try to match the best, from competition, where those ahead try to destroy those further behind. Their arguments along those lines actually sound fairly modern in gamification. Points and banners were not payment, but just encouragement and recognition for engaged workers, providing indication and acknowledgment of progress, and a comradely way to guide workers towards where they should be going.

Workers were even encouraged to engage in more leisurely gamification not directly related to production, with scope for "end-user creativity". One factory held a competition among divisions to "elevate the cultural level of the workers", with entries including a division that decorated its work area with artificial palm trees [Austin, 2004, pp. 194-195]. Factory competitions could blend fuzzily into sports competitions: factories would not only compete against each other in production, but also field teams in soccer leagues [Riordan, 1980, ch. 5]. This attempted to leverage genuine game competition, together with cultural aspects such as local city pride and sports fandom, in an ambitious strategy of comprehensively gamifying industrial production.

\section{FUNSULTANTS AND WORK AS PLAY}

It's understandable that leftists might debate how to replace the notions of work and wage-labor with something else, perhaps less alienating. Since the 1990 s, however, the idea that work needs to be replaced with a more playful no-

\footnotetext{
${ }^{1}$ This all despite the fact that Trotsky himself had been partly responsible for the original conception of socialist competition [Service, 2009, p. 269].
}

tion has become a popular view among management consultants. At first glance this is a bit strange: one can imagine why a communist would want to reconceptualize work as something other than wage-labor, but why does a capitalist have a problem with it, and find it in need of a revamp? Instead of trying to organize the workplace as a game, why not just organize it like a workplace, and, in the traditional manner, pay people the market value of their labor to perform whatever work the employer desires?

Among management consultants, there appear to be two main motivations for turning away from the traditional conception of work-for-pay. The first is more mercenary: some in business hope that there exist non-monetary incentives that can elicit additional labor, thereby motivating workers with things that are "free" (such as internal competitions and points), rather than having to pay out as many monetary incentives, such as traditional performance bonuses. The second worry is that certain kinds of productivity are simply impossible to monetarily incentivize, and instead require somehow producing intrinsically motivated, happy workers.

This idea seems to have largely caught on with 301 Ways To Have Fun At Work [Hemsath and Yerkes, 1997], a survey of things companies had started doing to inject fun into the workplace. This book focuses mostly on "fun" in a general sense rather than "play" or "games" per se, though there are a few examples of turning corporate training seminars into games. A book in a similar vein, but written at a considerably more rigorous level, followed the next year: Corporate Celebration: Play, Purpose, and Profit at Work [Deal and Key, 1998]. It placed a bit more emphasis on targeted celebrations and team-building activities, to make employees feel appreciated and part of a family.

An early prominent critique, albeit not a particularly academic one, comes in the 1999 film Office Space. In one scene, employees are expected to express their creativity and the fun of their workplace by wearing "pieces of flair" pinned to their clothing. Not all employees appreciate this mandatory enthusiasm, and, at least in the film, it ends up seeming a rather dystopian perversion of fun. The general style of workplace gamification in this example has some similarity to the workplace-palm-tree example in the Soviet Union: a recurring theme in both the Soviet and the 1990s "funsultant" version of fun-at-work is to include not only play elements that are directly connected to work (such as points for performance, or competitions), but also elements that attempt to make workers feel like they have a stake and expressive role in their workplace.

The turn of the 21st century saw a flurry of activity. The best-seller Fish! A Remarkable Way to Boost Morale and Improve Results [Lundin et al., 2000] uses an anecdotal story of employees having fun at the Pike Place Fish Market to promote reconceptualizing the drudgery of work as a fun, engaging experience. The same year, Lessons from the Sandbox: Using the 13 Gifts of Childhood To Rediscover the Keys to Business Success [Gregerman, 2000] looks back to childhood play, and "explores 13 key gifts or talents we all possess naturally as kids that are also essential to success in the business world". The advice here is a bit banal and vague, but proposes a fun workplace where employees play together, with the subsidiary inclusion of a few segments advising that you set up games that motivate work goals. Parts are hard to read without thinking of the dystopian-forced-play critique leveled by Office Space, with one example in the book 
involving laughter-count targets:

\section{Take Stock of Your Commitment to Play}

Now make a log of your workday that records how much time you devote to playing, having fun, and actually engaging the world around you. Then note the number of times you and your colleagues laugh. Use this "inventory" as a baseline for redefining the role of play and fun in your performance.

The following year, we find Fun and Gains: Motivate and Energize Staff with Workplace Games, Contests and Activities [Greenwich, 2001]. Parts are a rehash of the late-1990s books, but this one features an increased focus specifically on using contests to motivate employees.

Around this time, the academic management literature began publishing a smattering of articles investigating the fun-at-work trend. Redman and Mathews [2002] found mixed results, cataloguing some benefits and some problems. Some research began to focus on the impacts on employee morale, as well as cataloguing subjective employee opinions (and how that might be modulated by demographics, types of job, etc.). Other research attempted to quantify whether this funification trend actually had measurable impacts on corporate profits. In the latter line of investigation, a $\mathrm{PhD}$ thesis, Who Put the Fun in Functional? Fun at Work and its Effects on Job Performance [Fluegge, 2008] claimed to find fairly positive empirical results.

The end of the decade saw academic attention arrive from outside the business-management literature, most of it critical. The main cluster theorizes fun-at-work, gamificationof-work, and corporate play as new forms of informal control by corporations over their employees, and in particular, forms of control that try to harness traditionally nonemployment-oriented values such as "self-expression" within the workplace context.

Among works in this vein, several representative examples can be mentioned. The book-length survey Authenticity and the Cultural Politics of Work: New Forms of Informal Control [Fleming, 2009], devotes a chapter (chapter 3) to "the antimonies of corporate 'fun'", arguing in part (as the title hints) that workplace fun is an attempt to harness the previously subversive character of informal games that employees play at work, incorporating even those into the official job, which coopts them into a way of informally directing work (but directing it nonetheless). Fleming and Sturdy [2011] expand on similar themes, and discuss the role of play at work as something to divert attention from more traditional methods of control that might otherwise prove unpopular.

Fisher [2009], as part of a larger investigation into the way modern corporations oddly reproduce some of the features of Stalinist management style (large, dysfunctional bureaucracy, with a demand that workers not only obey, but actively profess to love it), recalls Office Space's critique of self-expression and being-yourself in a corporate context:

Here, staff are required to decorate their uniforms with "seven pieces of flair", (i.e. badges or other personal tokens) to express their "individuality and creativity": a handy illustration of the way in which "creativity" and "self-expression" have become intrinsic to labor in Control societies; which, as Paolo Virno, Yann Moulier Bou- tang and others have pointed out, now makes affective, as well as productive demands, on workers. Furthermore, the attempt to crudely quantify these affective contributions also tells us a great deal about the new arrangements. The flair example also points to another phenomenon: hidden expectations behind official standards. Joanna, a waitress at the coffee chain, wears exactly seven pieces of flair, but it is made clear to her that, even though seven is officially enough, it is actually inadequate - the manager asks if she wants to look the sort of person "who only does the bare minimum".

Focusing more on games per se rather than self-expression, Andersen [2009], in a Foucauldian critique, analyzes the increasing use of games in workplaces as a reorientation of power away from explicit, hierarchical forms. Where the boss and chain of authority may have structured work via openly expressed fiat, such power-wielding looks increasingly clumsy, and is in the process of being replaced by methods that simultaneously structure work while claiming to suspend their own power to do so, having turned it over to more distributed, apparently autonomous decision-making within game-like frameworks. He later expands this into a general theory of "hybrid forms of governance", of which workplace gamification is one [Andersen, 2012]. These constitute approaches to organizational management (especially corporate management) that simultaneously want to exercise traditional control, while also suspending such traditional control: "deparadoxification machines" that try to find ways to tell employees, "Do as I say. Be autonomous."

\section{CONCLUSIONS}

There are at least two precursors to the gamification-ofwork movement, and associated literatures advocating for each: an early to mid 20th century period in the Soviet Union, which tried such experiments in the context of an attempted move away from capitalist work relations; and a more recent period in the West, which tried such experiments, instead, in the context of an attempted move within capitalist workplaces towards offices that are more efficient and harmonious. What remains to be seen is what lessons can be learned from these experiments, what similarities today's gamification-of-work movement may have with such precursors, and, perhaps especially, how the critiques of these previous efforts can be addressed in today's. The current assumption of many gamification proponents appears to be that there are few precursors to their efforts, which obscures such historical lessons.

There are likely also genuinely novel, unexplored elements in the more recent gamification-of-work efforts, which might, too, be better understood if viewed against this history. One line of thought posits a generational change caused by today's younger workers having grown up playing videogames. In contrast to the focus on childhood play in some of the fun-at-work literature, such a hypothesis argues that in the videogame era, game mechanics are deeply embedded in people's thought processes in a way that is qualitatively different from the relationship previous generations had with games and play. Thus, rather than business harnessing the "lessons from the sandbox" of Gregerman [2000], perhaps there are new "lessons from the Xbox" to harness, where videogames 
with their mechanics, rather than open-ended playground fun, represent the most promising reference point for workplace management to mine. Deterding [2012] traces the origin of this gamer-generation argument-while criticizing it - to the book Got Game: How the Gamer Generation is Reshaping Business Forever [Beck and Wade, 2004].

A key conflation is between many of these related concepts: fun, game, play. The gamification-of-work movement, compared to what I'm grouping under the fun-at-work label, puts more focus on motivational techniques borrowed from games, rather than entertainment techniques; nonetheless, a certain undertone of effortless fun is often present in gamification advocacy, and game-like elements were some of the more prominent concrete features of fun-at-work proposals.

The Soviet approach may have the most direct similarities to gamification of work, since there the focus was squarely on motivating productivity, and negotiating (in at times a very modern-seeming way) the rough waters between intrinsic motivation, competitive sentiment, performance measurement and metrics, and extrinsic rewards. Since Soviet workplace management is not widely considered a model to emulate (to put it mildly), a key question is whether it serves primarily as a negative case study, or whether some of the gamification ideas themselves were good, but poorly implemented in the context of a Stalinist political system. The Soviet attempt degenerated into bureaucratization and an increasingly totalitarian version of "competition" that reached its height during the Stakhanovite and shock-brigade period. In that period, "socialist emulation" became a dystopian management culture in which workers were expected to "voluntarily" meet ever-higher production quotas. Milder echoes of that potential failure case, where internal games de facto become a means of setting quotas, can also be found in the critiques of fun-at-work. However, a full postmortem does not seem to have been carried out, to clarify what really took place in the largest real-world example of workplace gamification.

\section{References}

N. A. Andersen. Power at Play: The Relationships between Play, Work and Governance. Palgrave Macmillan, 2009.

N. A. Andersen. Introduction. In N. A. Andersen and I.-J. Sand, editors, Hybrid Forms of Governance: Selfsuspension of Power. Palgrave Macmillan, 2012.

R. C. Austin. Building Utopia: Erecting Russia's First Modern City, 1930. Kent State University Press, 2004.

J. C. Beck and M. Wade. Got Game: How the Gamer Generation Is Reshaping Business Forever. Harvard Business Review Press, 2004.

M. Burke and T. Hiltbrand. How gamification will change business intelligence. Business Intelligence Journal, 16(2): 8-16, 2011.

T. E. Deal and M. K. Key. Corporate Celebration: Play, Purpose, and Profit at Work. Berrett-Koehler, 1998.

S. Deterding. Experts split, hold various opinions. http://gamification-research.org/2012/05/ experts-split-hold-various-opinions-on-possiblefuture-of-gamification/, 2012. Blog post (May 20, 2012).
S. Deterding, D. Dixon, R. Khaled, and L. Nacke. From game design elements to gamefulness: Defining 'gamification'. In Proceedings of the 15th International Academic MindTrek Conference, pages 9-15, 2011.

M. Fisher. Capitalist Realism: Is There No Alternative? Zer0 Books, 2009.

P. Fleming. Authenticity and the Cultural Politics of Work: New Forms of Informal Control. Oxford University Press, 2009.

P. Fleming and A. Sturdy. 'Being yourself' in the electronic sweatshop: New forms of normative control. Human Relations, 64(2):177-200, 2011.

E. R. Fluegge. Who Put the Fun in Functional? Fun at Work and its Effects on Job Performance. PhD thesis, University of Florida, 2008.

C. Greenwich. Fun and Gains: Motivate and Energize Staff with Workplace Games, Contests and Activities. McGrawHill, 2001.

A. Gregerman. Lessons from the Sandbox: Using the 13 Gifts of Childhood To Rediscover the Keys to Business Success. McGraw-Hill, 2000.

D. Hemsath and L. Yerkes. 301 Ways to Have Fun at Work. Berrett-Koehler, 1997.

S. Kotkin. Peopling Magnitostroi: The politics of demography. In W. G. Rosenberg and L. H. Siegelbaum, editors, Social Dimensions of Soviet Industrialization. Indiana University Press, 1993.

V. I. Lenin. How to organise competition? In Collected Works, Volume 26 (September 1917 - February 1918). Progress, 1917/1964.

S. C. Lundin, H. Paul, and J. Christensen. Fish! A Remarkable Way to Boost Morale and Improve Results. Hyperion Books, 2000

T. Redman and B. P. Mathews. Managing services: Should we be having fun? The Service Industries Journal, 22(3): 51-62, 2002.

J. Riordan. Sport in Soviet Society. Cambridge University Press, 1980.

R. Service. Trotsky: A Biography. Harvard University Press, 2009.

R. E. Silverman. Latest game theory: Mixing work and play. Wall Street Journal, 2011. (October 9, 2011) http://online.wsj.com/article/ SB10001424052970204294504576615371783795248.html.

R. Smith. The future of work is play: Global shifts suggest rise in productivity games. In Proceedings of the 2011 IEEE Games Innovation Conference, pages 40-43, 2011.

J. V. Stalin. Emulation and labour enthusiasm of the masses. In Works, Volume 12 (April 1929 - June 1930). Foreign Languages Publishing House, 1929/1954.

L. Trotsky. The Revolution Betrayed. Dover, 1937/2004. Translator, Max Eastman.

I. Zemtsov. Socialist competition. In Encyclopedia of Soviet Life, pages 293-295. Transaction, 1991. 